\title{
ARTICLES
}

Submitted 05.15.2018. Approved 05.07.2019

Evaluated through a double-blind review process. Scientific Editor: Fernanda Perobelli

Original version

DOI: http://dx.doi.org/10.1590/So034-759020190402

\section{CONDITIONAL PRICING MODEL WITH HETEROSCEDASTICITY: EVALUATION OF BRAZILIAN FUNDS}

\author{
Modelo de precificação condicional com heteroscedasticidade: Avaliação de \\ fundos brasileiros
}

\section{Modelo de valoración condicional con heteroscedasticidad: Evaluación de fondos brasileños}

\begin{abstract}
Empirical studies have revealed that the conditional Capital Asset Pricing Model (CAPM) has a higher explanatory power than its unconditional version, particularly for the model in state-space form where the beta is estimated using Kalman filter. Most empirical analyses are based on stock portfolios to explain financial anomalies, but only a few studies proposed improving investment fund performance. The main contribution of this study is the assessment of Brazilian investment funds through traditional measures estimated from the CAPM model in state-space form with heteroscedastic and homoscedastic errors compared to alternative models, such as the unconditional CAPM and a four-factor model. Using a sample of stock funds from May 2005-April 2015, the results indicate that the conditional CAPM model produces better results than the alternative models, providing better performance evaluation practices for funds in both stock-picking and market-timing ability.
\end{abstract}

KEYWORDS | Conditional Capital Asset Pricing Model, Kalman filter, time-varying betas, investment funds, performance analysis.

LEANDRO SANTOS DA COSTA ${ }^{1}$ leandrosdcosta@gmail.com ORCID: 0000-0003-2183-8796

FRANCES FISCHBERG BLANK ${ }^{1}$ francesblank@puc-rio.br ORCID: 0000-0002-2022-4226

\section{FERNANDO LUIZ CYRINO OLIVEIRA $^{1}$}

cyrino@puc-rio.br

ORCID: 0000-0003-1870-9440

\section{CRISTIAN ENRIQUE MUÑOZ \\ VILLALOBOS ${ }^{2}$}

crisstrink@gmail.com

ORCID: 0000-0002-7563-8469

'Pontifícia Universidade Católica do Rio de Janeiro, Departamento de Engenharia Industrial, Rio de Janeiro, RJ, Brasil

${ }^{2}$ Pontifícia Universidade Católica do Rio de Janeiro, Departamento de Engenharia Elétrica, Rio de Janeiro, RJ, Brasi

\section{RESUMO}

Os resultados empíricos na literatura demonstram que a versão condicional do Modelo de Precificação de Ativos Financeiros (CAPM), particularmente no que se refere ao modelo na forma em espaço de estado, no qual o beta é estimado pelo filtro de Kalman, possui maior poder explicativo do que a sua versão incondicional. A maioria das análises empíricas na literatura baseia-se em portfólios de ações para explicar anomalias financeiras, porém poucos estudos propõem-se a melhorar a avaliação de desempenho de fundos de investimento. A principal contribuição deste artigo consiste em avaliar fundos de investimento brasileiros por meio de medidas tradicionais estimadas a partir do CAPM na forma em espaço de estado com erros heteroscedásticos e homoscedásticos e comparar seus resultados com modelos alternativos, tais como CAPM incondicional, modelo de quatro fatores. Utilizando uma amostra de fundos de ações, os resultados indicam que o modelo CAPM con dicional produz melhores resultados do que os modelos alternativos, proporcionando melhores práticas de avaliação de desempenho em relação às habilidades de stock-picking e market-timing.

PALAVRAS-CHAVE / Modelo de precificação de ativos financeiros condicional, filtro de Kalman, betas variantes no tempo, fundos de investimento, análise de performance.

\section{RESUMEN}

Los resultados empíricos en la literatura revelan que la versión condicional del CAPM, particularmente con respecto al modelo en forma de espacio de estado, en el cual se estima beta mediante el filtro de Kalman, posee mayor poder explicativo que su versión incondicional. La mayoría de los análisis empíricos se basan en carteras de valores para explicar anomalías financieras, pero pocos estudios proponen mejorar el rendimiento de los fondos de inversión. La principal contribución de este estudio a la literatura es que lleva a cabo la evaluación de fondos de inversión a través de medidas condicionales generadas a partir del CAPM en forma espacio-estado con errores heteroscedásticos y homoscedásticos y que compara sus resultados con modelos alternativos, tales como CAPM incondicional, modelo de cuatro factores. Utilizando una muestra de fondos de acciones, los resultados indican que el modelo CAPM condicional produce mejores resultados que los modelos alternativos, proporcionando mejores prácticas de evaluación de desempeño en relación con las habilidades de stock-picking y market-timing.

PALABRAS CLAVE I Modelo de valoración de activos de capital condicional, filtro de Kalman, betas variantes en el tiempo, fondos de inversión, análisis de rendimiento. 


\section{INTRODUCTION}

Empirical studies have shown the failures of the capital asset pricing model (CAPM) through consistently different returns from those predicted by the model. Since the development of the Fama and French (1993) and Carhart (1997) factor models, several studies have used these models in the performance analysis of investment funds to evaluate to what extent the returns could be attributed to two main managerial skills: stock-picking and market-timing. While the former concerns the manager's ability to select the best assets for a given level of risk, the latter refers to managing the funds' beta in anticipation of future market movements.

In general, the evidence shows that after considering all fund expenses, managers do not have stock-picking ability (Carhart, 1997; Elton, Gruber, \& Blake, 2012; Fama \& French, 2009). The results are more controversial for market-timing, with some authors pointing to evidence of positive managerial timing (Bollen \& Busse, 2000; Busse, 1999; Ferson \& Schadt, 1996) while many others pointing to the lack of this ability (Elton et al., 2012; Treynor \& Mazuy, 1966).

In Brazil, the conclusions regarding managers' abilities vary greatly depending on the sample and the proposed model. In general, there are more positive results reported than in the international literature (Borges \& Martelanc, 2015). Using the one-factor model and variations of CAPM, Eid and Rochman (2006) found evidence of superior performance of stock funds in relation to the market; Leusin and Brito (2008) observed positive and significant alphas, as well as weak evidence for few managers with market timing ability; and Matos and Nave (2012) verified the persistence among better performing funds. However, Casaccia, Galli, Macêdo, and Leitao (2011) did not identify any special abilities of managers in their sample. There are other studies on Brazilian funds using factor models where, in most cases, no superior managerial skills are evident. Castro and Minardi (2009) used the three-factor model (E. F. Fama \& French, 1993) and four-factor model (Carhart, 1997), along with a fifth factor on market timing. The authors did not observe stock-picking ability of managers on comparing active and passive funds. Jordão and Moura (2011) analyzed an extensive sample from Carhart (1997) model for stock-picking ability and from Treynor and Mazuy (1966) for market-timing and found that less than $5 \%$ of the funds presented positive and significant results for such skills. Nerasti and Lucinda (2016) investigated the persistence in the performance of Brazilian stock funds with four models: traditional CAPM, the three-factor model proposed by Fama and French (1993), Carhart's four-factor model (1997), and an additional model, adding the risk factor associated with asset liquidity. They did not find persistence in the superior performance of Brazilian managers. Borges and Martelanc (2015) estimated the alphas in a sample comparing real funds and synthetic funds using the four-factor model of Carhart (1997) and found managers' positive ability to generate abnormal returns, albeit modest.

Since managers assume different levels of risk depending on the kind of fund, empirical evidence shows that funds generally do not maintain constant levels of risk over time (Lee \& Rahman, 1990; Mamaysky, Spiegel, \& Zhang, 2008), which is different from the assumption in the unconditional CAPM and traditional factor models. Therefore, a more accurate modelling of the temporal variation in the fund's risk should result in a more realistic assessment of its performance.

The conditional version of CAPM was developed to address the limitations of the traditional static version. There are three main approaches to model the dynamic behavior of the beta: (i) modelling the conditional distribution function of returns as an explicit function of lagged conditioning variables (Jagannathan \& Wang, 1996; Lettau \& Ludvigson, 2001), (ii) describing the beta dynamics using conditional or stochastic volatility models (Bodurtha Jr \& Mark, 1991; Bollerslev, Engle, \& Wooldridge, 1988; Yu, 2002), (iii) using state-space models where the beta dynamics are directly modelled as a stochastic process (Adrian \& Franzoni, 2009; Blank, Samanez, Baidya, \& Aiube, 2014; Jostova \& Philipov, 2005; Mergner \& Bulla, 2008).

Several studies have indicated that the conditional state-space CAPM specification provides more accurate estimates of beta than the others (Adrian \& Franzoni, 2009; Faff, Hillier, \& Hillier, 2000; Mergner \& Bulla, 2008). Moreover, such differences are more pronounced in daily data than in monthly data (Bollen \& Busse, 2000). One problem with financial returns is the temporal dependence on its conditional variancethe presence of heteroscedasticity. However, most studies assumed that the conditional CAPM residuals are homoscedastic, despite empirical tests finding high heteroscedasticity even after the conditional treatment of the model (Mergner \& Bulla, 2008). Ortas, Salvador, and Moneva (2015) constructed the heteroscedastic version of the conditional CAPM model using the Kalman filter algorithm, where the errors are modelled as a generalized autoregressive conditional heteroscedasticity (GARCH) process. The results show that the heteroscedastic model surpasses the homoscedastic model in in-sample and out-of-sample analysis.

For Brazil, Tambosi Filho, Garcia, Imoniana, and Moreiras (2010) test a conditional CAPM incorporating macroeconomic 
and financial variables and verify a significant increase in the explanatory power of the model. Using a state-space form conditional CAPM, Mazzeu, Da Costa Júnior, and Santos (2013) observed a reduction in pricing errors using the time-varying beta model in a sample of 13 stocks in the Brazilian market. Blank et al. (2014) build portfolios of stocks based on book-tomarket and market value characteristics and verify that when the beta is modeled as a random walk with conditioning variables, pricing errors are reduced. Caldeira, Moura, and Santos (2013 use a similar approach in combining a dynamic conditional covariance matrix based on a GARCH model and the risk factors proposed by Carhart (1997) with time-varying coefficients. The authors observe satisfactory results compared to benchmark models.

Some international authors propose incorporating temporal dynamics in systematic risk. Ferson and Schadt (1996), based on a conditional model where the funds' betas depend on lagged variables, analyze a sample of US funds and find that both static CAPM and a conditional factor model produce a negative alpha more often than positive ones. The results show that the conditional model eliminates evidence of negative timing of managers found by the unconditional model.

Holmes and Faff (2008) compare conditional CAPM based on lagged variables and state-space conditional CAPM using an Australian funds sample. While the first model shows the presence of stock-picking ability, it is not observed in the statespace model. Similarly, Mamaysky et al. (2008) find the alpha and beta estimates of a large sample of US funds. Their predictions estimated through the Kalman filter are more accurate than those of ordinary models.

The literature in Brazil does not use conditional models to analyze managers' abilities and compare those models with traditional approaches, such as the unconditional CAPM and multifactor models. This paper aims to fill this gap, with two main objectives: (i) to evaluate conditional CAPM models in the space-state form applied to a sample of Brazilian stock funds; this is estimated from the Kalman filter with the errors of the regression equation in homoscedastic (SS-HOM) and heteroscedastic (SS-HET) forms, and (ii) to analyze how using traditional measures obtained from the conditional CAPM model can improve the current practice of evaluating the performance of investment funds and managers' abilities of stock-picking and market timing, compared to alternative models, such as the unconditional CAPM and the Carhart's (1997) four-factor model.

Using selected Brazilian funds, the results show that the modelling of the heteroscedastic structure of the errors increases the CAPM conditional capacity to capture the alpha and beta temporal dynamics of investment funds. Given the superiority of the proposed conditional models, this study then evaluates the performance of stocks funds from 02/05/2005 to 30/04/2015. Evidence suggests that managers' ability to select the best assets is directly related to significant appreciation in the stock market and that managers do not have the ability to anticipate periods of appreciation and fall in the market.

The rest of this paper is organized as follows. The following section presents the econometric models of asset pricing. Then, the performance of the CAPM models in the state-space form with residuals of the homoscedastic and heteroscedastic observation equation is analysed. Next, the empirical application of the models is carried out, and, finally, the conclusions of the research are presented.

\section{MODEL AND ESTIMATION PROCEDURE}

The appeal of CAPM, developed independently by Sharpe (1964), Lintner (1965), and Mossin (1966), lies in its simplicity, where the expected return for a given asset is given as:

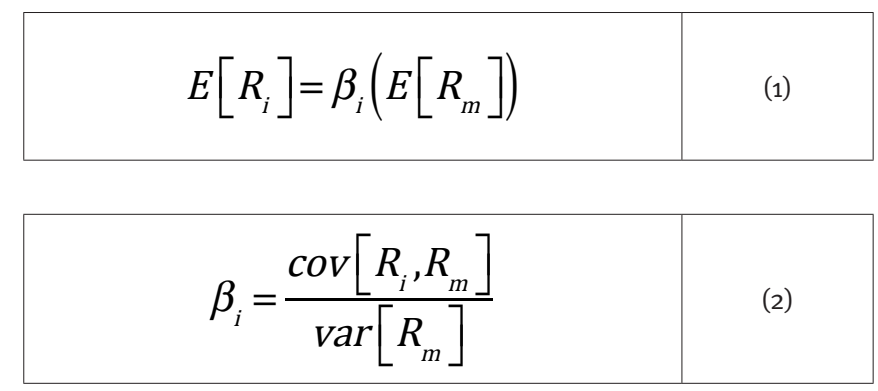

where $R i$ and $R m$ are the excess returns on asset $i$ and the market portfolio in relation to the risk-free asset, respectively, and $\beta i$ is a risk measure that is not eliminated through diversification, also known as systematic risk or beta.

However, one critical limitation of CAPM is its static nature. In such a hypothesis, the presence of anomalies could be due to beta time-varying dynamics that are not captured by CAPM in its original form. Preserving the structure of one model factor, different models are used to capture the time-varying systematic risk, with the conditional models in state-space usually giving the best results.

The model described by equations (1) and (2) is built on expected values and is, therefore, non-observable. It is commonly tested on time series using observable measures of realized returns. Thus, considering a classic Gaussian univariate linear 
regression model, the conditional version with time-varying alpha and beta can be written as the state-space model given by equations (3) to (5).

$$
R_{i, t}=\alpha_{i, t}+\beta_{i, t} R_{m, t}+\in_{i, t}, \quad \in_{i, t} \sim N\left(0, \sigma_{\in i}^{2}\right), t=1, \ldots n
$$

$$
\alpha_{i, t+1}=\alpha_{i, t}+\vartheta_{i, t}, \quad \vartheta_{i, t} \sim N\left(0, \sigma_{\vartheta i}^{2}\right)
$$

$$
\beta_{i, t+1}=\beta_{i, t}+\eta_{i, t}, \quad \quad \eta_{i, t} \sim N\left(0, \sigma_{\eta i}^{2}\right)
$$

Equation (3) is known as observation one and (4) and (5) are the state equations. It is usually assumed that errors $\epsilon_{i, t}, \vartheta_{i, t}$, and $\eta_{i, t}$ are serially independent and homoscedastic and $\alpha_{i, t}$ is known as Jensen's alpha.

The intercept is statistically assumed to be zero in CAPM, which means that the market risk premium adjusted by the assets' beta would be sufficient to explain the observed returns. However, if a portfolio manager can better forecast asset prices, higher returns than the ones implied in the model could be obtained, and Jensen's alpha could represent an average incremental return rate of the portfolio by the unit of time exclusively due to the manager's ability. In an unconditional form, equation (3) would be estimated by ordinary least squares (OLS) where alpha and beta are constant over time.

A random walk process describes the alpha and beta time-varying dynamics. Pizzinga and Fernandes (2006) outlined three main reasons for justifying such a choice: (i) parsimony, (ii) simplicity, and (iii) the possibility of fundamental managerial changes over time due to the non-stationary property.

The specification of the model in equations (3) to (5) allows the direct application of Kalman filter to estimate time-varying and constant parameters (Adrian \& Franzoni, 2009; Faff et al., 2000; Mergner \& Bulla, 2008). The constant parameters are estimated, in particular, through prediction error decomposition and maximization of the log-likelihood function given by:

$$
\log L\left(\psi_{i}\right)=-\frac{n}{2} \log 2 \pi-\frac{1}{2} \sum_{t=1}^{n}\left(\log \left|F_{t}\left(\psi_{i}\right)\right|+\frac{V_{t}\left(\psi_{i}\right)}{F_{t}\left(\psi_{i}\right)}\right)
$$

where $\psi_{i}=\left(\sigma_{\epsilon, i}^{2}, \sigma_{\vartheta, i}^{2}, \sigma_{\eta, i}^{2}\right)$ is the hyper-parameter vector of the model; $v_{t}\left(\psi_{i}\right)=R_{i}-E\left[R_{i} \mid \Omega_{t-1}, \psi_{i}\right]$ and $F_{t}\left(\psi_{i}\right)=\operatorname{Var}\left(v_{t}\left(\psi_{i}\right)\right)$ are calculated through Kalman filter, known as one-step-ahead prediction error and its variance, respectively, and $\Omega_{t-1}=\left\{R_{1}, \ldots, R_{t-1}\right\}$. In this study, state vectors $\beta_{t}$ and $\alpha_{t}$ follow random walk processes and the Kalman filtering used is in its diffuse exact form.

Nonetheless, the volatility clusters, especially in the daily asset returns series, are responsible for creating a structure of time dependent conditional variance in this series, which are not captured by the model described in equations ( 3 ) to (5). In this context, Ortas et al. (2015) propose a heteroscedastic version of the conditional CAPM model estimated by Kalman filter algorithm, where the errors of the regression equation are modelled with conditional variance according to a GARCH $(1,1)$ process:

$$
\in_{i, t} \mid \Omega_{t-1} \sim N\left(0, \sigma_{\in i, t}^{2}\right), \quad \Omega_{t-1}=\left\{R_{1}, \ldots, R_{t-1}\right\}
$$




$$
\sigma_{\in i, t}^{2}=\omega_{i}+\rho \epsilon_{i, t-1}^{2}+\gamma \sigma_{\epsilon i, t-1}^{2}, \quad \omega_{i}>0, \rho_{i}, \gamma_{i} \geq 0 e \rho_{i}+\gamma_{i}<1
$$

The estimated model specified in equations (3)-(5) and (7)-(8) follows the iterative procedure proposed by Ortas et al. (2015). The process maximizes a partial log-likelihood function assuming constant mean parameters and then maximizes a partial loglikelihood function assuming constant variance parameters. The parameters are estimated based on the Kalman Filter algorithm. The procedure alternates between those two steps until it achieves convergence.

Two well-established models in asset-pricing literature used in performance analysis of investment funds are also estimated for comparison purposes. The first is the unconditional CAPM, tested on the time series using observable measures of realized returns, estimated from equation (9). The estimation is performed using OLS with rolling windows of 120 days, which is a commonly used alternative in the ad hoc attempt to adjust the time-varying coefficients of the model.

$$
R_{i t}=\alpha_{i}+\beta_{i}\left(R_{m t}\right)+\varepsilon_{i t}
$$

where $\varepsilon_{i t}$ is the i.i.d. error term, with $E\left(\varepsilon_{i t}\right)=0$ and $\operatorname{Var}\left(\varepsilon_{i t}\right)=\sigma_{\varepsilon i}^{2}$.

The second approach is Carhart's (1997) four-factor model given in equation (10).

$$
R_{i, t}=\alpha_{i}+\beta_{i M} R_{M, t}+\beta_{i S} S M B_{t}+\beta_{i H} H M L_{t}+\beta_{i W} W M L_{t}+\varepsilon_{i t}
$$

where $S M B_{t}$ captures the anomaly in the size of the company; $H M L_{t}$ captures the anomaly in the book-to-market ratio; and $W M L_{t}$ captures the anomaly in the moment of stocks. Again, OLS is used with rolling windows of 120 days for the estimation.

\section{MODEL PERFORMANCE}

This section comparatively analyses the performance of conditional CAPM models in state-space form for homoscedastic and heteroscedastic observation equation errors and compares these results with well-established models.

\section{Data}

The data for this study were obtained from the Quantum Axis online database. We selected the funds classified in the category 'Stocks', such as 'Free Stocks', which had a complete sample from February 5, 2005 to April 30, 2015, totaling 2,474 daily observations for each series. This time span was used because it coincides with a period of accelerated development of the Brazilian funds industry.

It is worth mentioning that the selected sample might present survival bias since the sample comprises funds that have survived during the period of time analyzed. However, studies have shown (Brown, Goetzmann, Ibbotson \& Ross, 1992; Carvalho, 2005) that the inclusion of bias in the end result of performance analysis measures is minimal, with a positive bias on mean returns from $0.2 \%$ to $0.8 \%$ per year. Still, according to Milan and Eid (2014), in the Brazilian market, the main reason for a majority of investment funds to terminate is their merger with other funds, not poor performance.

Both the fund quotas used as the market indexes were adjusted for the distribution of dividends and are net of the taxes charged by funds. We used the arithmetic return as a measure of daily return of the funds, calculated based on excess return in relation to the risk-free rate.

Table 1 presents the main descriptive statistics for the daily return series. The funds are organized in descending order of the total accumulated returns in the analyzed period. A greater number of selected funds show a mean positive return for the period. Funds with the worst positions show average negative returns, which indicates that they did not show the capacity to overcome the risk-free assets, once the results shown are in terms of return excess. The Ljung-Box test applied to the squared returns confirms the heteroscedasticity of the daily returns financial series once the statistical value of the test for all funds rejects the null hypothesis that the autocorrelation of the series equals zero at the significance level of $1 \%$. 
Table 1. Descriptive statistics of excess return series of funds

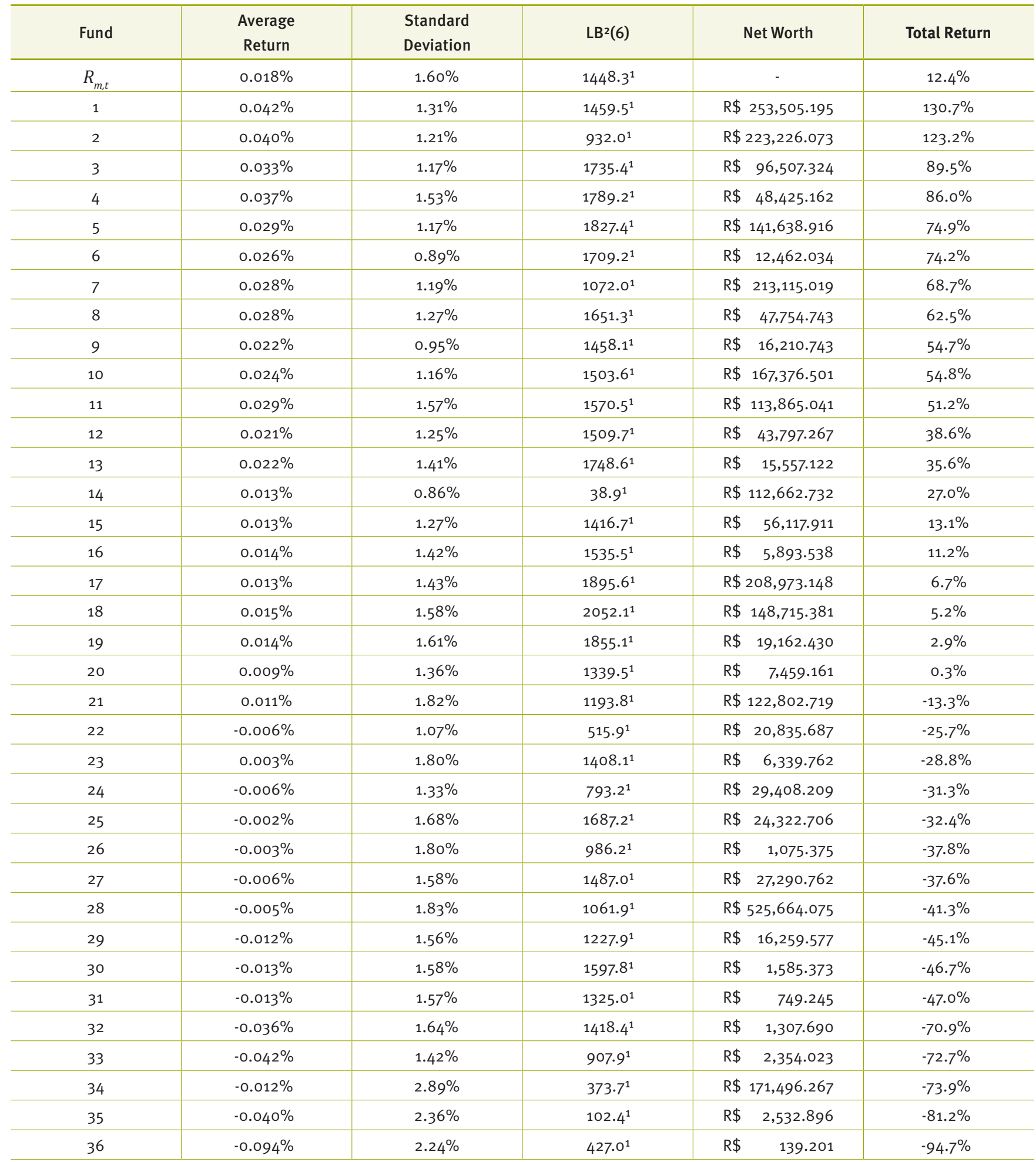

Notes: ${ }^{1,2,3}$ Significant at the $1 \%, 5 \%$, and $10 \%$ level, respectively.

This table shows the basic descriptive statistics of the daily fund returns from May 2, 2005 to April 30, 2015. JB is the Jarque-Bera normality test. ADF is the augmented Dickey-Fuller test for unit root. LB2 is the Ljung-Box test applied to the squared returns. The number of 'lags' is determined according to Tsay (2010): $\operatorname{Ln}(2474)=7.81 \cong 8$. The return in the period is calculated as the accumulated return for the entire sampling period. 


\section{Model Estimates}

Here, we analyze the constant parameter estimates of the conditional CAPM in state-space form when the observation equation residuals, $\epsilon_{i, t}$, are homoscedastic (SS-HOM), in equations (3) to (5), and heteroscedastic (SS-HET), in equations (3) to (5) and (7) and (8).

The results for the SS-HOM and SS-HET constant parameter estimation for each of the sample funds are shown in Table 2.
Like in other studies, we observe that the funds' betas seem to follow a time-varying dynamic process once the parameters $\sigma_{\eta, i}^{2}$ are statistically different from zero, at the $1 \%$ significance level, for 34 out of the 36 sample funds. Regarding investment funds, this result is expected since the forecasting strategies used by managers and/or the variation in stock beta that are part of their portfolios generate variations in funds' betas. It is worth noting that the constant parameter estimates are lesser for the SS-HET model than for the SS-HOM model.

\section{Table 2.SS-HOM and SS-HET model estimates}

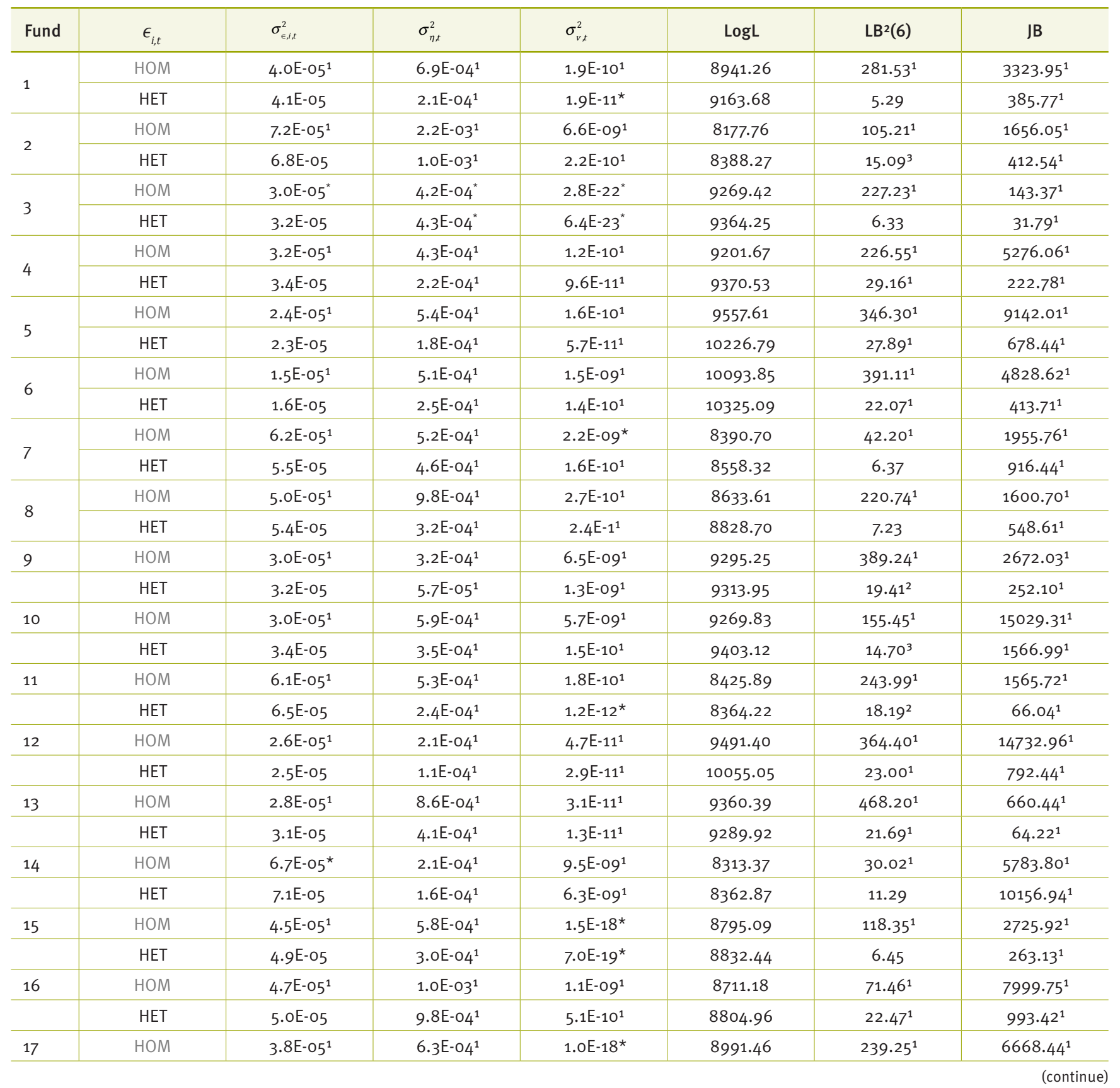


Table 2.SS-HOM and SS-HET model estimates

(continuation)

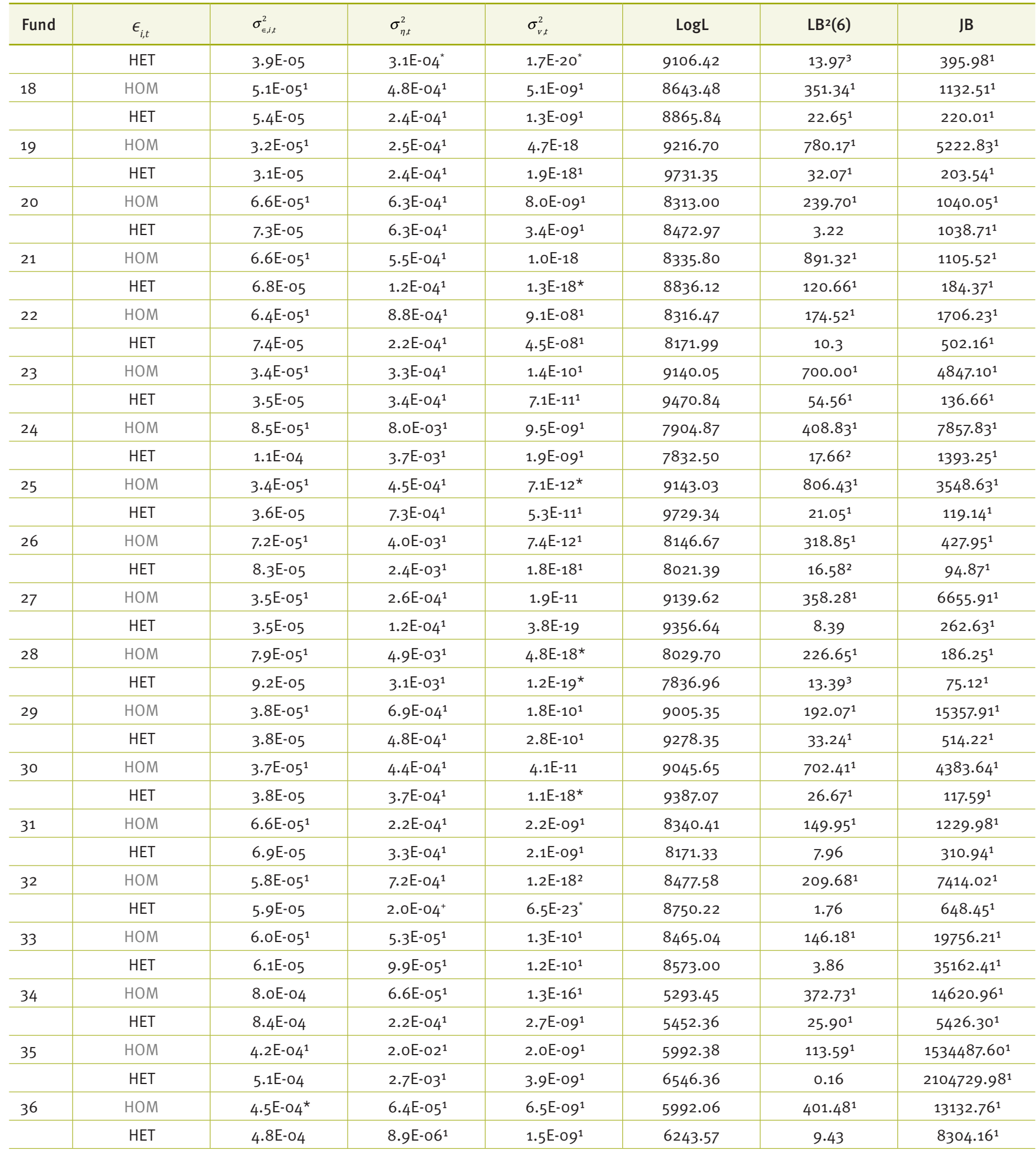

Notes: ${ }^{1},{ }^{2},{ }^{3}$ Significant at the $1 \%, 5 \%$, and $10 \%$ level, respectively; ${ }^{*}$ Significance not measured by the program.

The second column represents the assumption for residue $\epsilon_{t}$ of the observation equation (HOM: homoscedastic or HET: heteroscedastic). The next three columns represent the hyper-parameter variance maximum likelihood estimates, for observation equations $\left(\sigma_{e}^{2}\right)$ and the state variables $\left(\sigma_{n}^{2} \sigma_{v}^{2}\right)$. The error variance of the observation equation refers to the unconditional variance of $\epsilon_{t}$ LB $^{2}$ refers to the Ljung-Box test applied to the standardized squared residuals of the models. The number of lags is determined as in Tsay (2010): $\operatorname{Ln}(2474)=7.81 \cong 8$. JB refers to the Jarque-Bera normality tests. 
With regard to the time-varying dynamics of alpha for the 26 sample funds, it is possible to reject the null hypothesis $\left(\sigma_{\vartheta, i}^{2}\right.$ to be statistically zero). However, it is observed that their estimates are close to zero. This suggests that the alpha parameter related to the managers' stock-picking ability gradually varies over time.

\section{Goodness of fit Measure of Models}

The SS-HOM and SS-HET models discussed in the previous section are comparatively assessed in this subsection. We use the following measures to test the goodness of fit: Akaike's information criterion (AIC), Bayesian information criterion (BIC), root mean square error (RMSE), and mean absolute error (MAE). For the residual diagnostic tests, we utilize the Jarque-Bera (JB) and Ljung-Box (LB) tests.

Table 3 shows the AIC and BIC for the SS-HOM and SS-HET models for all the sample funds. The majority of funds, 26 out of the 36, show lower AIC and BIC values for the heteroscedastic model than for the homoscedastic model, thereby indicating that the approach of the heteroscedastic structure of errors $\epsilon_{t}$ increases the capacity of the conditional CAPM model to capture the time-varying dynamics of alpha and beta in the sample funds.

\section{Table 3.Goodness-of-fit measures}

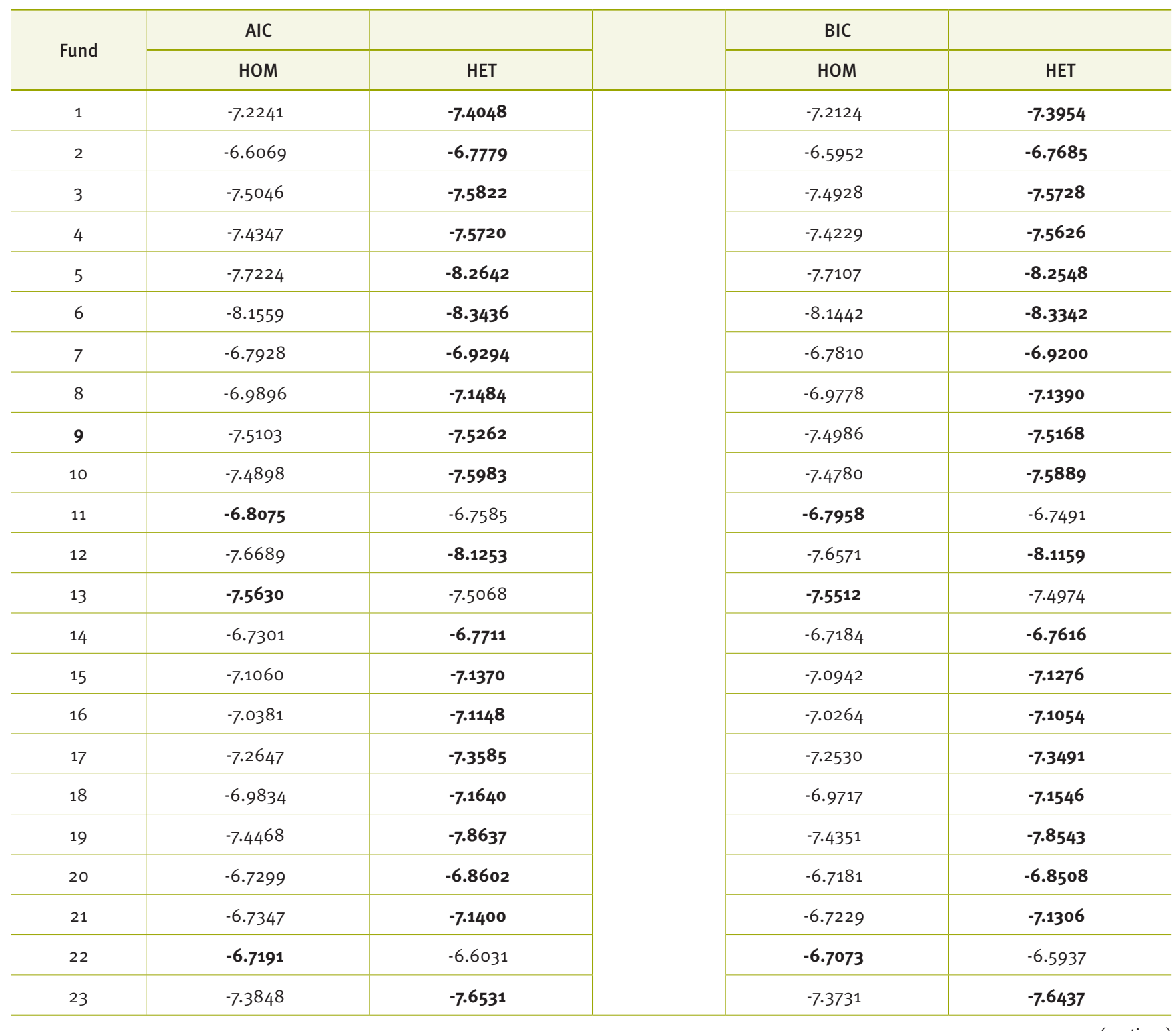


Table 3.Goodness-of-fit measures

(continuation)

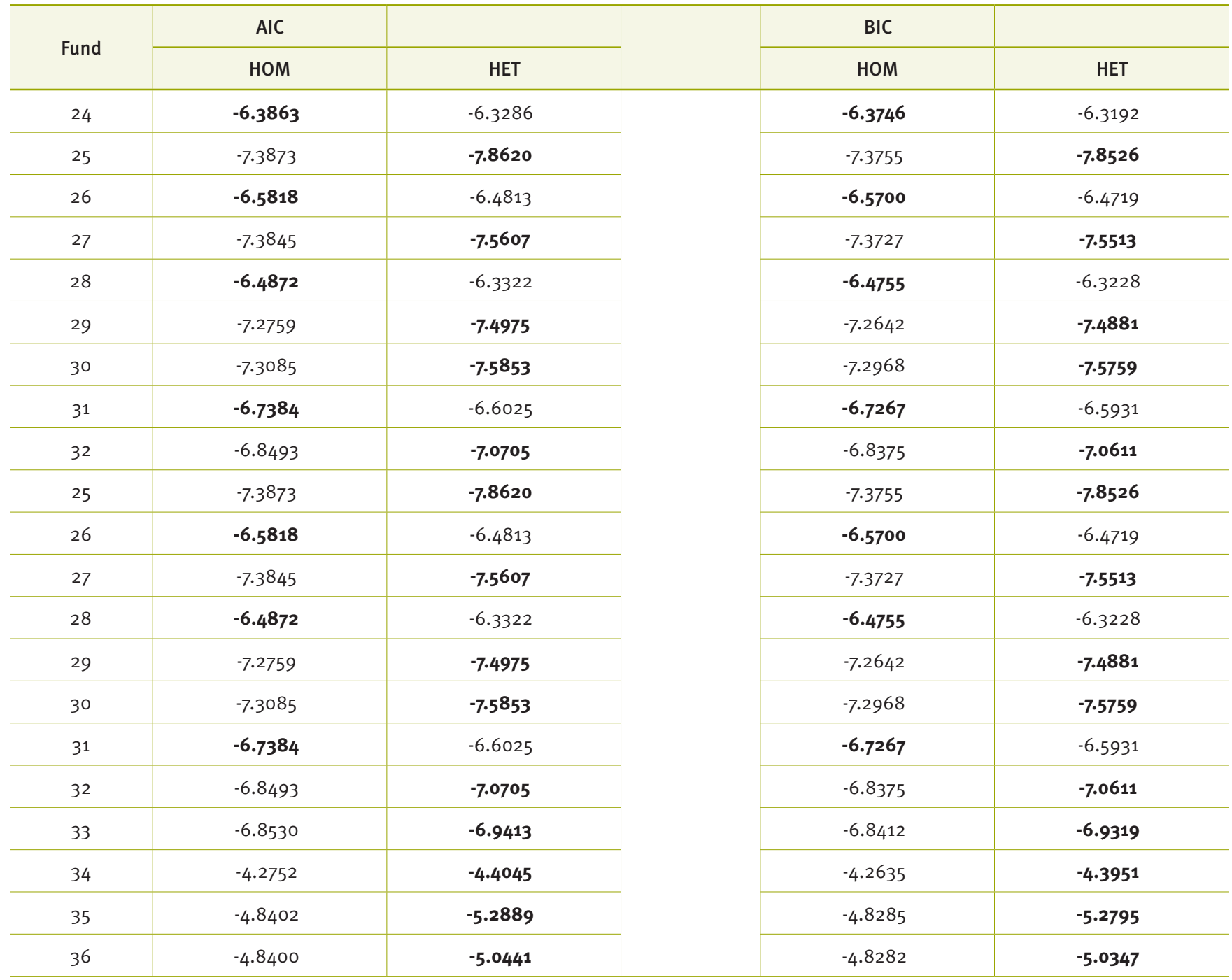

Notes: AIC is Akaike information criterion and BIC is Bayesian information criterion. The higher measures are in bold.

Other measures used for the explanatory power analysis are RMSE and MAE. The in-sample forecast returns were estimated for each time $t$ from January 2, 2006 to April 30, 2015 totaling 2,305 observations.

Apart from the results shown for the SS-HOM and SS-HET models, we analyze the performance of the unconditional CAPM and the four-factor model of Carhart (1997) using OLS with rolling windows of 120 days.

Considering the explanatory, not predictive, objective of this analysis, for conditional CAPM models in space-state form estimated by Kalman filter algorithm, the smoothed versions of the state variables are used. Table 4 shows the sample average RMSE and MAE for each model.
The results in Table 4 show that the rolling windows approach could be better when the alpha and beta are time-varying and the RMSE and MAE tests for the SS-HOM and SS-HET models are inferior to the CAPM and the factors model. Hence, in the comparison between conditional models and the factors model, the results are favorable for conditional models, showing that considering in-sample explanatory power and time-varying alpha and beta could bring superior benefits to the introduction of more risk factors. Conversely, the comparison between SS-HOM and SS-HET models suggests a preference for the homoscedastic model, showing a lower RMSE and MAE on average. From the viewpoint of the model's explanatory power, the heteroscedastic model does not seem to obtain better results than the homoscedastic model, in general. 


\section{Table 4. Consolidated result of the in-sample goodness of fit of the 36 sample funds}

\begin{tabular}{l|c|c}
\hline Model & RMSE & MAE \\
\hline SS-HOM & $8.00 \mathrm{E}-03$ & $5.36 \mathrm{E}-03$ \\
\hline SS-HET & $8.15 \mathrm{E}-03$ & $5.43 \mathrm{E}-03$ \\
\hline CAPM & $8.56 \mathrm{E}-03$ & $5.77 \mathrm{E}-03$ \\
\hline Factors model & $8.37 \mathrm{E}-03$ & $5.68 \mathrm{E}-03$ \\
\hline
\end{tabular}

Notes: Each cell shows the sample average RMSE and MAE for each model.

\section{Residual Diagnostic Tests}

The results of the residual diagnostic tests are shown in Table 2, in columns 7 and 8, for JB and LB tests, respectively.

The normality hypothesis of standardized residual for both SS-HOM and SS-HET models is rejected for all the analyzed funds in the JB test. We observe a reduction in the latter compared to the former even though the t-statistic value for the SS-HET model is distant from the values of a normal standard distribution.
The SS-HOM model is not able to capture the heteroscedasticity in the residuals, once the null hypothesis of non-autocorrelation of the squared standardized residuals is rejected for all funds in the LB test. Conversely, this hypothesis is not rejected for the squared standardized residuals of the SS-HET model for 14 out of the 36 sample funds. The finding that 22 out of the 36 analyzed sample funds still feature such dependence structure in standardized residuals of SS-HET model requires further investigation.

Therefore, we analyze the correlograms of funds that persistently show heteroscedasticity signs in the residuals of the SS-HET model. Figure 1 shows two examples of this analysis. As with all the other funds not shown here, we observe that despite the values of residual autocorrelation being statistically different from zero, they are not relevant. In comparison, Figure 2 shows the correlograms of the standardized residuals of the SS-HOM model for the same funds. This comparison shows that the SS-HET model better captures the time-dependence structure of return series variance, given the substantial decrease in autocorrelation among the residuals.

\section{Figure 1. Standardized squared residuals correlograms for SS-HET model}

\begin{tabular}{|c|c|c|c|c|c|c|}
\hline Autocorrelation & Partial Correlation & & $\mathrm{AC}$ & PAC & Q-Sat & Prob \\
\hline 中 & 中 & 1 & 0.055 & 0.055 & 7.0703 & 0.008 \\
\hline & 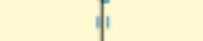 & 2 & 0.003 & -0.000 & 7.0869 & 0.029 \\
\hline 1 & 1 & 3 & 0.007 & 0.007 & 7.1971 & 0.066 \\
\hline f & t & 4 & 0.064 & 0.063 & 16.520 & 0.002 \\
\hline f & 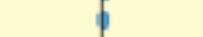 & 5 & 0.044 & 0.037 & 20.926 & 0.001 \\
\hline$b$ & $\varnothing$ & 6 & 0.034 & 0.030 & 23.621 & 0.001 \\
\hline 1 & 1 & 7 & -0.001 & -0.005 & 23.623 & 0.001 \\
\hline t & $\phi$ & 8 & 0.042 & 0.038 & 27.707 & 0.001 \\
\hline 1 & 1 & 9 & -0.030 & -0.040 & 29.756 & 0.000 \\
\hline$b$ & $\phi$ & 10 & 0.038 & 0.036 & 33.056 & 0.000 \\
\hline & $\varnothing$ & 11 & 0.018 & 0.011 & 33.770 & 0.000 \\
\hline t & 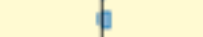 & 12 & 0.079 & 0.073 & 48.151 & 0.000 \\
\hline f & $\phi$ & 13 & 0.046 & 0.040 & 53.130 & 0.000 \\
\hline 1 & 1 & 14 & 0.001 & $=0.007$ & 53.132 & 0.000 \\
\hline & $\phi$ & 15 & 0.019 & 0.018 & 54.000 & 0.000 \\
\hline 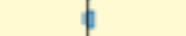 & 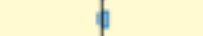 & 16 & 0.060 & 0.044 & 62.345 & 0.000 \\
\hline 1 & 1 & 17 & 0.017 & 0.004 & 63.033 & 0.000 \\
\hline 1 & 1 & 18 & -0.015 & -0.027 & 63.528 & 0.000 \\
\hline b & b & 19 & 0.029 & 0.030 & 65.483 & 0.000 \\
\hline f & 1 & 20 & 0.010 & -0.006 & 65.701 & 0.000 \\
\hline 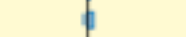 & b & 21 & 0.042 & 0.039 & 69.882 & 0.000 \\
\hline 1 & 1 & 22 & -0.004 & -0.011 & 69.911 & 0.000 \\
\hline t & 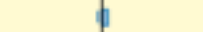 & 23 & 0.047 & 0.042 & 75.060 & 0.000 \\
\hline 1 & 1 & 24 & 0.010 & -0.004 & 75.295 & 0.000 \\
\hline 1 & 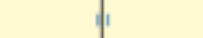 & 25 & 0.006 & -0.004 & 75.386 & 0.000 \\
\hline d & 1 & 26 & -0.022 & -0.028 & 76.539 & 0.000 \\
\hline 1 & 1 & 27 & -0.008 & -0.020 & 76.701 & 0.000 \\
\hline 1 & 1 & 28 & 0.001 & -0.006 & 76.702 & 0.000 \\
\hline 1 & 1 & 29 & 0.017 & 0.005 & 77.405 & 0.000 \\
\hline d & 1 & 30 & -0.016 & -0.008 & 77.981 & 0.000 \\
\hline 1 & 1 & 31 & -0.007 & -0.013 & 78.086 & 0.000 \\
\hline 1 & $\phi$ & 32 & -0.001 & 0.000 & 78.090 & 0.000 \\
\hline
\end{tabular}

\begin{tabular}{|c|c|c|c|c|c|c|}
\hline Autocorrelation & Partial Correlation & & $\mathrm{AC}$ & PAC & Q-Sat & Prob \\
\hline 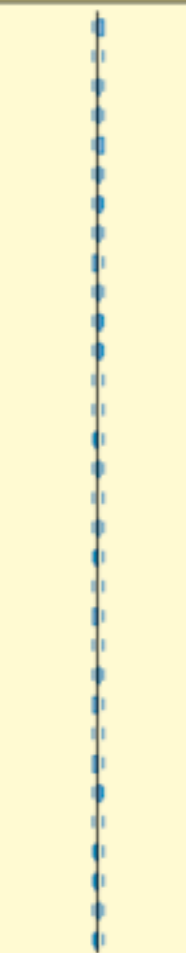 & $b_{1}^{1}$ & $\begin{array}{l}1 \\
2 \\
3 \\
4 \\
5 \\
6 \\
7 \\
8 \\
9 \\
10 \\
11 \\
12 \\
13 \\
14 \\
15 \\
16 \\
17 \\
18 \\
19 \\
20 \\
21 \\
22 \\
23 \\
24 \\
25 \\
26 \\
27 \\
28 \\
29 \\
30 \\
31 \\
32\end{array}$ & $\begin{array}{r}0.064 \\
-0.008 \\
0.015 \\
0.011 \\
0.054 \\
0.025 \\
0.027 \\
0.023 \\
-0.025 \\
0.013 \\
0.039 \\
0.039 \\
-0.006 \\
0.002 \\
-0.011 \\
0.009 \\
0.003 \\
0.012 \\
-0.010 \\
-0.006 \\
-0.026 \\
0.008 \\
0.025 \\
-0.031 \\
-0.001 \\
-0.039 \\
0.027 \\
-0.000 \\
-0.017 \\
-0.023 \\
0.024 \\
-0.022\end{array}$ & $\begin{array}{r}0.064 \\
-0.012 \\
0.016 \\
0.009 \\
0.053 \\
0.018 \\
0.026 \\
0.019 \\
-0.029 \\
0.013 \\
0.034 \\
0.032 \\
-0.013 \\
0.004 \\
-0.014 \\
0.007 \\
-0.003 \\
0.010 \\
-0.014 \\
-0.003 \\
-0.025 \\
0.009 \\
0.020 \\
-0.034 \\
0.005 \\
-0.038 \\
0.035 \\
-0.008 \\
-0.012 \\
-0.024 \\
0.034 \\
-0.024\end{array}$ & $\begin{array}{l}9.5223 \\
9.6631 \\
10.164 \\
10.453 \\
17.117 \\
18.512 \\
20.217 \\
21.471 \\
22.908 \\
23.282 \\
26.815 \\
30.335 \\
30.416 \\
30.425 \\
30.692 \\
30.870 \\
30.886 \\
31.237 \\
31.475 \\
31.562 \\
33.123 \\
33.270 \\
34.668 \\
36.960 \\
36.963 \\
40.455 \\
42.117 \\
42.117 \\
42.814 \\
44.067 \\
45.431 \\
46.517\end{array}$ & $\begin{array}{l}0.002 \\
0.008 \\
0.017 \\
0.033 \\
0.004 \\
0.005 \\
0.005 \\
0.006 \\
0.006 \\
0.010 \\
0.005 \\
0.002 \\
0.004 \\
0.007 \\
0.010 \\
0.014 \\
0.021 \\
0.027 \\
0.036 \\
0.048 \\
0.045 \\
0.058 \\
0.056 \\
0.044 \\
0.058 \\
0.035 \\
0.032 \\
0.042 \\
0.047 \\
0.047 \\
0.046 \\
0.047\end{array}$ \\
\hline
\end{tabular}

Note: This figure shows the correlograms of the standardized residuals of the SS-HET model for funds 05 (left) and 25 (right). 
Figure 2. Standardized squared residuals correlograms for SS-HOM model

\begin{tabular}{|c|c|c|c|c|c|c|c|c|c|c|c|c|c|}
\hline Autocorrelation & Partial Correlation & & $\mathrm{AC}$ & PAC & Q-Sat & Prob & Autocorrelation & Partial Correlation & & $\mathrm{AC}$ & PAC & Q-Sat & Prob \\
\hline 上 & 上 & 1 & 0.182 & 0.182 & 76.123 & 0.000 & $\square$ & $\square$ & 1 & 0.305 & 0.305 & 214.54 & 0.000 \\
\hline 要 & f & 2 & 0.121 & 0.091 & 110.04 & 0.000 & 巨 & 6 & 2 & 0.165 & 0.079 & 277.42 & 0.000 \\
\hline 审 & p & 3 & 0.107 & 0.074 & 136.59 & 0.000 & 巨 & E & 3 & 0.220 & 0.166 & 389.56 & 0.000 \\
\hline E & G & 4 & 0.163 & 0.129 & 198.33 & 0.000 & 巨 & g & 4 & 0.190 & 0.086 & 473.13 & 0.000 \\
\hline F & 5 & 5 & 0.122 & 0.065 & 232.90 & 0.000 & 巨 & 6 & 5 & 0.193 & 0.102 & 559.42 & 0.000 \\
\hline 百 & f & 6 & 0.126 & 0.072 & 269.80 & 0.000 & 巨 & f & 6 & 0.180 & 0.067 & 634.36 & 0.000 \\
\hline F & 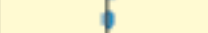 & 7 & 0.096 & 0.035 & 291.13 & 0.000 & E & $\zeta$ & 7 & 0.144 & 0.031 & 682.44 & 0.000 \\
\hline E & f & 8 & 0.153 & 0.096 & 345,02 & 0.000 & $巨$ & G & 8 & 0.232 & 0.144 & 807.24 & 0.000 \\
\hline 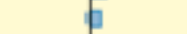 & I & 9 & 0.094 & 0.019 & 365.54 & 0.000 & F & 5 & 9 & 0.133 & -0.023 & 848.37 & 0.000 \\
\hline 巨 & t & 10 & 0.156 & 0.095 & 421.60 & 0.000 & 百 & t & 10 & 0.143 & 0.053 & 895.69 & 0.000 \\
\hline 巨 & e & 11 & 0.172 & 0.102 & 490.35 & 0.000 & 巨 & 日 & II & 0.244 & 0.135 & 1033.4 & 0.000 \\
\hline 巨 & G & 12 & 0.214 & 0.131 & 596.90 & 0.000 & 巨 & 6 & 12 & 0.246 & 0.110 & 1173.2 & 0.000 \\
\hline E & 5 & 13 & 0.128 & 0.032 & 634.84 & 0.000 & E & t & 13 & 0.141 & -0.022 & 1219.3 & 0.000 \\
\hline . & f & 14 & 0.095 & -0.001 & 655.61 & 0.000 & 巨 & b & 14 & 0.148 & 0.022 & 1270.1 & 0.000 \\
\hline f & t & 15 & 0.126 & 0.043 & 692.43 & 0.000 & F & f & 15 & 0.172 & 0.044 & 1338.4 & 0.000 \\
\hline 中 & 1 & 16 & 0.121 & 0.016 & 726.37 & 0.000 & 巨 & 1 & 16 & 0.138 & -0.016 & 1382.9 & 0.000 \\
\hline p & i & 17 & 0.087 & -0.003 & 744.15 & 0.000 & F & f & 17 & 0.127 & 0.008 & 1420.3 & 0.000 \\
\hline 5 & d & 18 & 0.058 & -0.033 & 751.98 & 0.000 & f & 1 & 18 & 0.078 & -0.051 & 1434.5 & 0.000 \\
\hline 五 & p & 19 & 0.116 & 0.043 & 783.39 & 0.000 & f & 1 & 19 & 0.087 & -0.024 & 1452.0 & 0.000 \\
\hline f & f & 20 & 0.092 & -0.005 & 803.17 & 0.000 & 5 & d & 20 & 0.088 & -0.028 & 1470.2 & 0.000 \\
\hline 6 & f & 21 & 0.132 & 0.054 & 843.86 & 0.000 & 6 & $b$ & 21 & 0.089 & 0.016 & 1488.5 & 0.000 \\
\hline 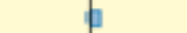 & 1 & 22 & 0.095 & -0.000 & 864.98 & 0.000 & E & f & 22 & 0.138 & 0.048 & 1533.0 & 0.000 \\
\hline E & f & 23 & 0.170 & 0.080 & 932.70 & 0.000 & 巨 & 6 & 23 & 0.173 & 0.056 & 1602.3 & 0.000 \\
\hline f & f & 24 & 0.075 & -0.035 & 945.73 & 0.000 & 6 & 1 & 24 & 0.105 & -0.009 & 1628.0 & 0.000 \\
\hline 6 & 1 & 25 & 0.102 & 0.018 & 970.00 & 0.000 & 耳 & 1 & 25 & 0.102 & 0.011 & 1652.1 & 0.000 \\
\hline 5 & d & 26 & 0.070 & -0.011 & 981.40 & 0.000 & 5 & 1 & 26 & 0.094 & -0.009 & 1672.7 & 0.000 \\
\hline f & i & 27 & 0.066 & -0.032 & 991.59 & 0.000 & E & p & 27 & 0.140 & 0.055 & 1718.5 & 0.000 \\
\hline 6 & $b$ & 28 & 0.098 & 0.038 & 1014.2 & 0.000 & 五 & 1 & 28 & 0.101 & -0.009 & 1742.3 & 0.000 \\
\hline 6 & 1 & 29 & 0.088 & 0.008 & 1032.5 & 0.000 & 五 & b & 29 & 0.110 & 0.039 & 1770.5 & 0.000 \\
\hline f & i & 30 & 0.074 & 0.016 & 1045.4 & 0.000 & f & 1 & 30 & 0.070 & -0.026 & 1782.1 & 0.000 \\
\hline 5 & i & 31 & 0.069 & -0.021 & 1056.7 & 0.000 & 6 & b & 31 & 0.099 & 0.030 & 1804.8 & 0.000 \\
\hline f & 1 & 32 & 0.069 & 0.002 & 1067.7 & 0.000 & f & 1 & 32 & 0.069 & -0.017 & 1815.8 & 0.000 \\
\hline
\end{tabular}

Note: This figure shows the correlograms of the standardized residuals of the SS-HOM model for funds 05 (left) and 25 (right).

Once the conditional models show a higher capacity to adjust to sample data, it is reasonable to suppose that the evaluation of performance measures obtained from this model might improve the actual performance evaluation.

\section{CONDITIONAL CAPM IN THE ANALYSIS OF BRAZILIAN EQUITY FUNDS}

This section uses the measures obtained from the conditional models to carry out the performance analysis of managers' stockpicking and market-timing abilities.

\section{Fund Performance Measures: Conditional Alphas}

The metric used here to compare fund performance is intercept $\alpha_{i, t}$ of equations (3), (9), and (10), also known as Jensen's alpha.

Since the objective of evaluation is to estimate the measures of performance evaluation from the impacts of different models, we built an equally weighted portfolio with all sample funds, in such a way that the portfolio returns in each period is given by mean returns of all funds in the same period. The portfolio's alpha estimates for each of the models are shown in Graph 1.

Unlike most of the previous studies, which usually deduce the existence of stock-picking ability by estimating the alpha in a given time span, our model allows us to obtain the alpha estimate at each instant of time, allowing the analysis of managers' stockpicking ability over time. In this sense, observing Graph 1, we can conclude that managers' ability to select the best assets is directly related to periods of market upswings (2007-2008 and 2009-2010). During periods of market downturn (20082009), managers, in general, deliver negative excess of return to their investors. Moreover, since the peak in 2010, managers' stock-picking ability has reduced gradually, having shown overall negative values in the last years of the sample.

A substantial difference can be noticed among the alpha estimates of each model, especially between the conditional models (SS-HOM and SS-HET) and the unconditional ones (unconditional CAPM and factors model), with the latter consistently higher than the former in absolute terms. One possible explanation for this phenomenon is that the lower 
explanatory power of the unconditional models, confirmed by the RMSE and MAE measures, tends to overestimate the values of alpha intercept estimates. Hence, the time-varying beta of funds would not be captured satisfactorily with the rolling windows estimates, being confused with positive or negative abnormal returns in the CAPM and factors models. This means that a portion of the alpha values estimated by the commonly used unconditional models do not deal with the superior ability of managers but only inadequately capture the temporal variation in the fund's beta.

\section{Graph 1. Alpha point estimates for an equally weighted portfolio for all sample funds}

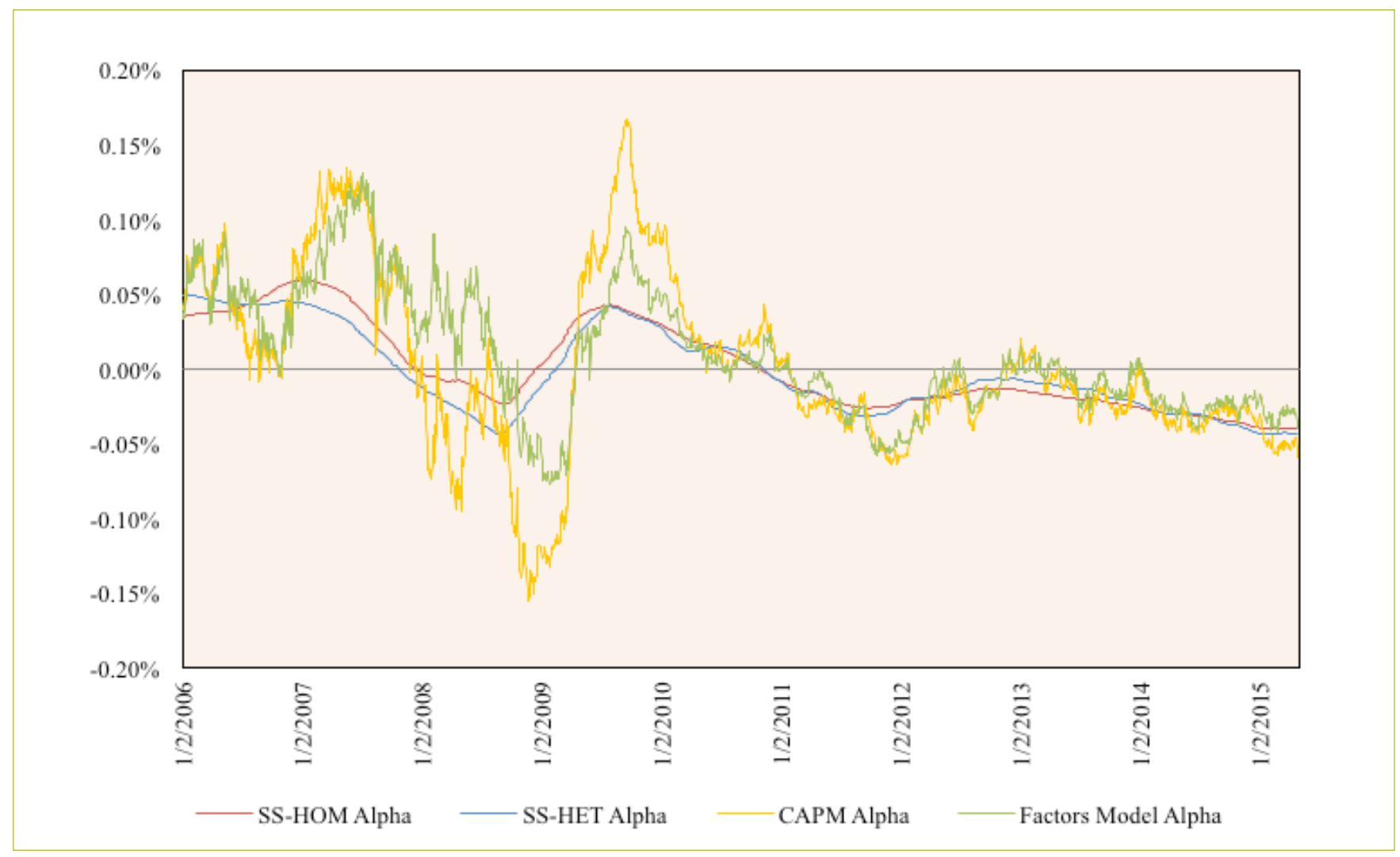

Note: This figure shows the portfolio's alpha estimates for the SS-HOM, SS-HET, CAPM, and factors models.

Thus, these results indicate four issues regarding managers' stock-picking ability: (1) the managers' ability to select the best assets might be directly related to periods of stock market upswings; (2) during periods of market downturns, the managers' search for assets with potential appreciation greater than their risk level incurred abnormal or negative returns; (3) managers have consistently showed negative alphas in the last years of the sample; and (4) in general, a portion of the alpha values estimated by the unconditional models are not due to the managers' stock picking ability, but merely the model's inability to adequately capture the temporal variation in the beta.

\section{Fund Performance Measures: Conditional Betas}

Since managers' market-timing ability is directly related to fund beta variation analysis over time, one must understand the evolution of estimated beta for the different models. Graph 2 shows the series of betas for some of the sample funds for SS-HOM and SS-HET models. A less noisy series of the SS-HET estimates than of the SS-HOM is observed in the first years of the sampling, especially between 2006 and 2008, a time of considerable market volatility caused by the global financial crisis of 2008 . Further investigation shows that the daily standard deviation of market factor returns of 2006-2008 (2.04\%) is higher than for 2009-2015 (1.29\%). According to Ortas et al. (2015), a less noisy estimate from the heteroscedastic model outperformance occurs because the leptokurtosis of the unconditional distribution of $\epsilon_{i, t}$ reduces the influence of outliers during the beta estimation process. In other words, periods of greater volatility would be marked by greater differences in the beta estimates-as is observed. 


\section{Graph 2. Beta point estimates for sample funds}
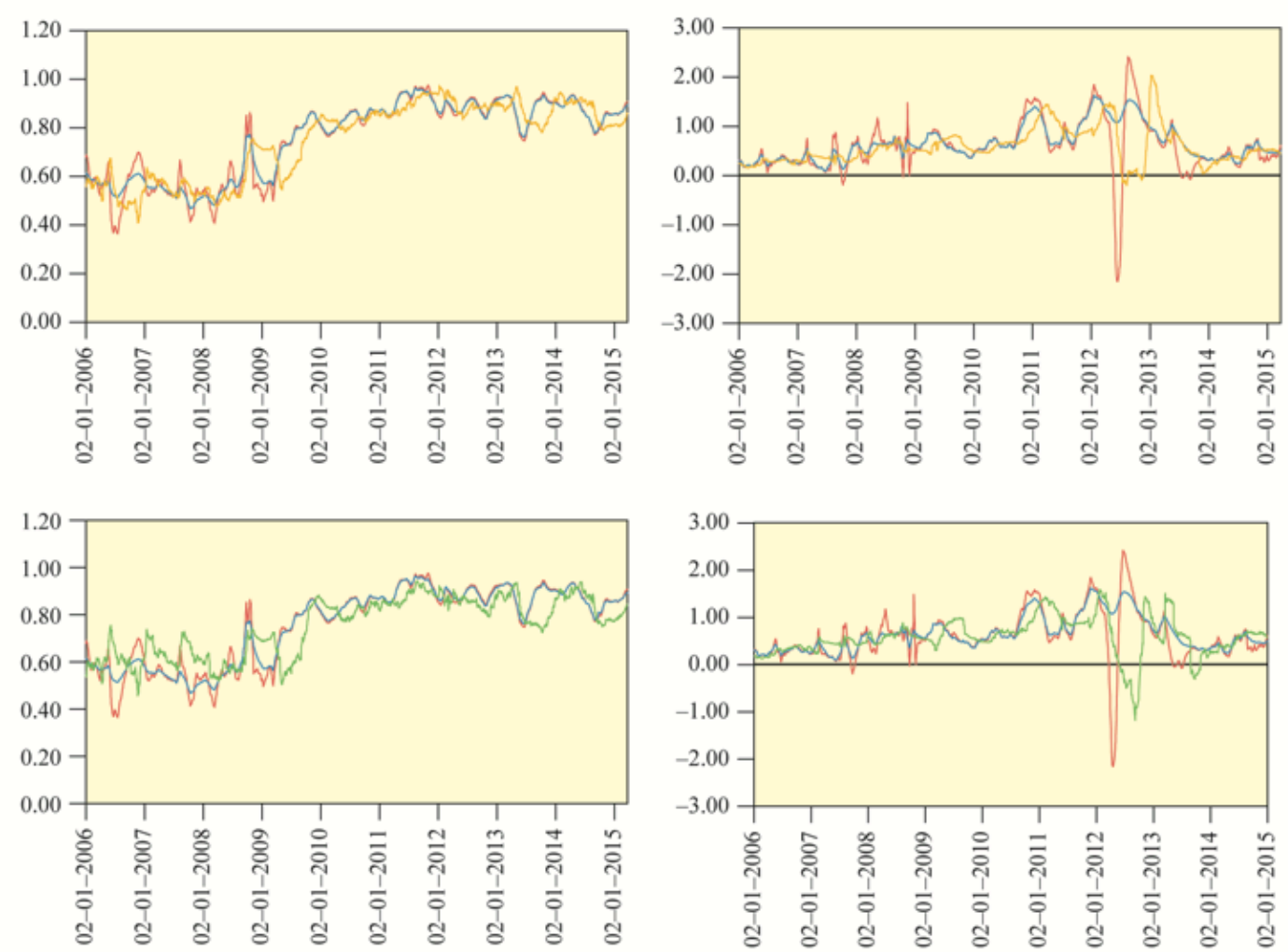

- SS-HOM beta — SS-HET beta

Regarding conditional and unconditional models, it can be noted that periods of rising beta for the former, in general, are periods of falling beta for the latter, and vice versa. Since the estimate for conditional beta in a given period is carried out conditionally on the information for the following periods, the smoothed estimates usually anticipate the future changes in the estimated variable.

To analyze managers' market-timing ability, we used the approach of Holmes and Faff (2008), where a daily series of beta estimated by conditional and unconditional models is used as a dependent variable in market factor regression, as presented in the following equation:

$$
\beta_{i, t}^{k}=\text { constant }+\gamma_{i}^{k} R_{m, t}+\varepsilon_{i, t}
$$

where subscript $i$ is the analysed sample fund and superscript $k$ the analyzed model; $\gamma_{i}^{k}$ is the regression coefficient, estimated by OLS; and $R_{m, t}$ represents the excess returns of the market factor. The manager shows market forecasting ability when $\gamma_{i}^{k}>0$.If $\gamma_{i}^{k}<0$ the manager increases beta during market downswing and lowers beta in market upswing.

The results of the estimates of $\gamma_{i}^{k}$ and their $p$-values are detailed in Table 5 . The use of SS-HOM and SS-HET conditional models reveals more funds for which managers' market-timing ability is negative than for the CAPM and factors models. Moreover, we verify a decrease in the mean coefficients of the sample funds $\gamma_{i}^{k}$ compared to the CAPM and factors models, which begin to show substantially negative values for conditional models. These results show that the conditional models alter the market-timing ability analysis compared to the CAPM and factors models, thereby indicating that the managers of the analyzed sample cannot forecast periods of market downturns or upswings, even when doing the opposite by systematically increasing beta funds during market downswings and decreasing beta funds during upswings. However, with regard to the comparison between the results of SS-HOM and SS-HET models, no significant differences are observed. 
Table 5. Comparison of market-timing coefficients $\gamma_{i}^{k}$ for the conditional CAPM and factors model

\begin{tabular}{|c|c|c|c|c|}
\hline & SS-HOM & SS-HET & CAPM & Factors model \\
\hline \multicolumn{5}{|l|}{ Panel A: summary statistics } \\
\hline No. of negative cases $\left(\gamma_{y}^{k}<0\right)$ & $33(8)$ & $34(6)$ & 15 & 23 \\
\hline \multicolumn{5}{|c|}{ Panel B: correlation coefficients between estimated beta series } \\
\hline SS-HOM & & 0.9715 & 0.7560 & 0.6728 \\
\hline
\end{tabular}

Notes: The numbers in brackets represent results that are statistically different from zero at the significance level of $10 \%$. Panel B shows the means correlation coefficients of the beta series for the 36 sample funds.

A negative coefficient related to market-timing ability warrants explanations. According to Ferson and Schadt (1996), a negative coefficient could arise when a manager has perverse ability to forecast market movement in the opposite direction. The negative correlation between the funds' beta and the market factor returns could also be caused by the flow of investment funds: since significant investments in funds tend to decrease its beta, they tend to increase during periods of market upswings. The explanation for managers' negative market-timing ability would be the significant flow of investments during market upswings.

Further, Panel B of Table 5 shows that, in general, there is a strong correlation between the beta estimates of conditional models. That could be one explanation for the market-timing results not displaying substantial differences. This correlation decreases when the estimates of conditional models are analyzed against other models, the conditional and factors models. This could explain the market-timing results displaying more significant differences among the different models.

\section{CONCLUSIONS}

The results obtained in this study show that the measures of the heteroscedastic Kalman Filter model provide better performance evaluation for funds regarding managers' ability in Brazilian stock funds, for stock-picking and market-timing, than the traditional models.
Unlike many previous papers, especially in the Brazilian context, a heteroscedastic version of conditional CAPM is compared with the results of the homoscedastic version of the model, and alternative models, such as the four-factor model of Carhart (1997). Keeping the one-factor model structure, the results show that the modelling of the heteroscedastic structure of errors increases the capacity of the conditional CAPM model to capture the funds' alpha and beta timing dynamics.

The state-space models were also compared for goodness of fit to the unconditional CAPM and four-factor model of Carhart (1997), both estimated with rolling-windows. The results indicate the superiority of the conditional models for all pricing measures used. These results suggest that the alpha and beta timing variation bring superior benefits than the introduction of more risk factors.

After the higher quality of goodness of fit to the conditional models is determined, the conditional measures of investment fund performance evaluation were estimated.

We can draw four conclusions regarding managers' stockpicking ability: (1) the managers' ability to better select assets can be directly related to periods of market upswings; (2) during periods of market downturns, the managers' search for better assets with an appreciation potential higher than their risk level, leads to abnormal negative returns; (3) managers have consistently shown negative alphas in the last years of the sample; and (4) in general, a portion of the alpha values estimated by the unconditional models do not show the presence of managers' stock picking ability but only an inability of the model 
to adequately capture the temporal variation in the beta. As for the market-timing ability, the results indicate that managers of the analyzed sample not only do not have forecasting ability for market downturns or upswings, rather end up doing just the opposite- systematically increasing (decreasing) fund betas in market downturns (upswings).

Further research in this area can be highlighted. Hybrid models combining the Kalman Filter approach and lagged macroeconomic variables as conditioning variables can bring more information on the managers' performance based on their strategies. Heteroscedastic multifactor models in the context of conditional pricing models with time-varying coefficients can bring even better results both in terms of goodness of fit and forecasting. That would be a step ahead from this paper. Particularly considering the methodology displayed here and given the potential different applications of Kalman filter basedmethods, equivalent procedures could be reproduced and applied to other areas of study in Finance and Economics. Finally, more sophisticated models based on machine learning techniques can also be an avenue of research in this area.

\section{REFERENCES}

Adrian, T., \& Franzoni, F. (2009). Learning about beta: Time-varying factor loadings, expected returns, and the conditional CAPM. Journal of Empirical Finance, 16(4), 537-556. doi:10.1016/j. jempfin.2009.02.003

Agudo, L. F., Magallón, M. V., \& Sarto, J. L. (2006). Evaluation of performance and conditional information: The case of Spanish mutual funds. Applied Financial Economics, 16(11), 803-817. doi:10.1080/09603100500397245

Blank, F. F., Samanez, C. P., Baidya, T. K. N., \& Aiube, F. A. L. (2014). CAPM condicional: Betas variantes no tempo no mercado brasileiro. Revista Brasileira de Finanças, 12(2), 163-199.

Bodurtha J. N., \& Mark, N. (1991). Testing CAPM with time-varying risks and returns. Journal of Finance, 46(4), 1485-1505. doi:10.2307/2328868

Bollen, N., \& Busse, J. (2001). On the timing ability of mutual fund managers. The Journal of Finance, 56(3), 1075-1094. doi:10.1111/00221082.00356

Bollerslev, T., Engle, R.F., \& Wooldridge, J. M. .(1988.). A capital asset pricing model with time-varying covariances. Journal of Political Economy, 96(1), 116-131.

Borges, E. C., \& Martelanc. (2015). Sorte ou habilidade: Uma avaliação dos fundos de investimento no Brasil. Revista de Administração, 50(2), 196-207. doi:10.5700/rausp1194

Brown, S. J., Goetzmann, W., Ibbotson, R. G. \& Ross, S. A. (1992). Survivorship bias in performance studies. The Review of Financial Studies, 5(4), 553-580.
Busse, J. A. (1999). Volatility timing in mutual funds: Evidence from daily returns. Review of Financial Studies, 12(5), 1009-1041. doi:10.1093/ $\mathrm{rfs} / 12.5 .1009$

Caldeira, J. F., Moura, G. V. \& Santos, A. P. (2013). Seleção de carteiras utilizando o modelo Fama-French-Carhart. Revista Brasileira de Economia, 67(1), 45-65. doi:10.1590/So034-71402013000100003

Carhart, M. M. (1997). On persistence in mutual fund performance. The Journal of Finance, 52(1), 57-82. doi:10.2307/2329556

Carvalho, M. R. A. (2005). Avaliação de desempenho de fundos multimercado: Resultados passados podem ser utilizados para definir uma estratégia de investimento? Revista de Economia $e$ Administração, 4(3), 367-387.

Casaccia, M. C., Galli, O. C., Macêdo, G. R., \& Leitao, C. (2011). Análise do desempenho de fundos de investimentos: Um estudo em ações brasileiras no período de janeiro de 2004 a agosto de 2009. Revista Organizações em Contexto, 7(13), 1-30. doi:10.15603/1982-8756/ roc. v7n13p1-30

Castro, B., \& Minardi, A. (2009). Comparação do desempenho dos fundos de ações ativos e passivos. Revista Brasileira de Finanças, 7(2), 143-161.

Cuthbertson, K., Nitzsche, D., \& O'Sullivan, N. (2008). UK mutual fund performance: Skill or luck? Journal of Empirical Finance, 15(4), 613634. doi:10.1016/j.jempfin.2007.09.005

Eid, W., \& Rochman, R. (2006). Fundos de investimento ativos e passivos no Brasil: Comparando e determinando seus desempenhos. Article presented in the thirtieth Encontro da ANPAD, Salvador, BA.

Elton, E. J., Gruber, M. J., \& Blake, C. R. (2012). An examination of mutual fund timing ability using monthly holdings data. Review of Finance, 16(3), 619-645. doi:10.1093/rof/rfroo7

Faff, R. W., Hillier, D., \& Hillier, J. (2000). Time varying beta risk: An analysis of alternative modelling techniques. Journal of Business Finance \& Accounting, 27(5-6), 523-554. doi:10.1111/14685957.00324

Fama, E. F., \& French, K. R. (1993). Common risk factors in the returns on stocks and bonds. Journal of Financial Economics, 33(1), 3-56. doi:10.1016/0304-405X(93)90023-5

Fama, E., \& French, K. (2009). Luck versus skill in the cross-section of mutual fund returns. Journal of Empirical Finance, 65(June), 1915 1947.

Ferson, W. E., \& Schadt, R. W. (1996). Measuring fund strategy and performance in changing economic conditions. Journal of Finance, 51(2), 425-461. doi:10.2307/2329367

Holmes, K. A., \& Faff, R. (2008). Estimating the performance attributes of Australian multi-sector managed funds within a dynamic Kalman filter framework. International Review of Financial Analysis, 17(5), 998-1011. doi:10.1016/j.irfa.2008.05.001

Jagannathan, R., \& Wang, Z. (1996). The conditional CAPM and the cross-section of expected returns. The Journal of Finance, 51(1), 3-53. doi:10.2307/2329301

Jordão, G. A., \& de Moura, M. L. (2011). Performance analysis of Brazilian hedge funds. Journal of Multinational Financial Management, 21(3), 165-176. doi:10.1016/j.mulfin.2011.02.002

Jostova, G., \& Philipov, A. (2005). Bayesian analysis of stochastic betas. The Journal of Financial and Quantitative Analysis, 40(4), 747-778. 
Laes, M. A., \& da Silva, M. E. (2014). Performance of mutual equity funds in Brazil-A bootstrap analysis. Economia, 15(3), 294-306. doi:10.1016/j.econ.2014.08.002

Lee, C. F.., \& Rahman, S. (1990). Market timing, selectivity, and mutual fund performance: An empirical investigation. The Journal of Business, 63(2), 261-278.

Lettau, M., \& Ludvigson, S. (2001). Resurrecting the (C)CAPM: A crosssectional test when risk premia are time-varying. Journal of Political Economy, 109(6), 1238-1287. doi:10.1086/323282

Leusin, L. de M.., \& Brito, R. D. (2008). Market timing e avaliação de desempenho dos fundos brasileiros. RAE-Revista de Administração de Empresas, 48(2), 22-36. doi:10.1590/S0034-75902008000200003

Lintner, J. (1965). The valuation of risk assets and the selection of risky investments in stock portfolios and capital budgets. The Review of Economics and Statistics, 47(1), 13-37. doi:10.2307/1924119

Mamaysky, H., Spiegel, M., \& Zhang, H. (2008). Estimating the dynamics of mutual fund alphas and betas. Review of Financial Studies, 21(1), 233-264.

Matos, P., \& Nave, A. (2012). Fundos de investimento em ações no Brasil: Performance e expertise de gestão. Brazilian Business Review, 9(Especial), 1-38.

Mazzeu, J. H. G., Da Costa Júnior, N. C. A. Da. \& Santos, A. A. P. (2013). CAPM condicional com aprendizagem aplicado ao mercado brasileiro de ações. RAM-Revista de Administração Mackenzie, 14(1), 143-175. doi:10.1590/S1678-69712013000100007

Mergner, S., \& Bulla, J. (2008). Time-varying beta risk of Pan-European industry portfolios: A comparison of alternative modeling techniques. The European Journal of Finance, 14(8), 37-41. doi:10.1080/13518470802173396
Milan, P. L. A. B., \& Eid, W. (2014). Elevada rotatividade de carteiras e o desempenho dos fundos de investimento em ações. Revista Brasileira de Finanças, 12(4), 469-497.

Mossin, J. (1966). Equilibrium in a capital asset market. Econometrica, 34(4), 768-783. doi:10.2307/1910098

Nerasti, J. N., \& Lucinda, C. R. (2016). Persistência de desempenho em fundos de ações no Brasil. Revista Brasileira de Finanças, 14(2), 269$-297$.

Ortas, E., Salvador, M., \& Moneva, J. M. (2015). Improved beta modeling and forecasting: An unobserved component approach with conditional heteroscedastic disturbances. North American Journal of Economics and Finance, 31, 27-51. doi:10.1016/j.najef.2014.10.006

Pizzinga, A., \& Fernandes C. (2006). State space models for dynamic style analysis of portfolios. Revista de Econometria, 26(1), 31-66. doi:10.1266o/bre.v26n12006.2497

Sharpe, W. F. (1964). Capital asset prices: A theory of market equilibrium under conditions of risk. The Journal of Finance, 19(3), 425-442. doi:10.2307/2977928

Tambosi Filho, E., Garcia, F. G., Imoniana, J. O., \& Moreiras, L. M. F. (2010). Teste do CAPM condicional dos retornos de carteiras dos mercados brasileiro, argentino e chileno, comparando-os com o mercado norte-americano. RAE-Revista de Administração de Empresas, 50(1), 60-74. doi:10.1590/S0034-75902010000100006

Treynor, J. L.., \& Mazuy, K. K. (1966)). Can mutual funds outguess the market? Harvard Business Review, 131-136.

Tsay, R. S. (2010). Analysis of Financial Time Series. John Wiley.

Yu, J. (2002). Forecasting volatility in the New Zealand stock market. Applied Financial Economics, 12(3), 193-202. doi:10.1080/09603100110090118 